\title{
SUPERHIGH ADSORPTION OF CADMIUM(II) IONS ONTO SURFACE MODIFIED NANO ZEROVALENT IRON COMPOSITE (CNS-NZVI): CHARACTERIZATION, ADSORPTION KINETICS AND ISOTHERM STUDIES
}

\author{
Prabu Deivasigamani ${ }^{1}$, Senthil Kumar Ponnusamy ${ }^{2}$, Sathish Sundararaman ${ }^{1,}$, Suresh $A^{1}$
}

https://doi.org/10.23939/chcht15.04.457

\begin{abstract}
The efficiency of surface modified nanoscale zerovalent iron (nZVI) composite by cashew nut shell (CNS) was tested for the removal of cadmium ions from the aqueous solutions. $2 \mathrm{~g} / \mathrm{l} \mathrm{CNS}-\mathrm{nZVI}$ was efficient for $98 \%$ removal. The adsorption capacity was $35.58 \mathrm{mg} / \mathrm{g}$. The Freundlich isotherm $\left(R^{2}=0.9769\right)$ and the pseudosecond order adsorption kinetics data fitted well. This proved CNS-nZVI has a high removal efficiency for $\mathrm{Cd}(\mathrm{II})$ from aqueous solutions.
\end{abstract}

Keywords: nanocomposite, cashew nut shell, adsorption, nZVI, isotherm, kinetics.

\section{Introduction}

Water is a valuable and accessible asset. Water plays a noteworthy role in sanitation, industrialization, and domestic purposes. Heavy metal contamination results from rapid industrialization. The toxic pollutants, like cadmium, nickel, lead, are discharged into the water through various sources and cause threat to the environment [1]. Among the toxic pollutants the major source of cadmium originates from industries like metal, phosphate fertilizers, electroplating, battery generation because of industrialization and anthropogenic activities [2, 3]. Exposure of cadmium causes problems in testosterone levels and also affects the organs like lungs, kidneys, liver [4]. The permissible limit of cadmium in consumable water proposed by WHO (2008) and EPA (2008) rules is 0.003 and $0.005 \mathrm{mg} / 1$, respectively [5]. A few strategies, for example, filtration by film, coagulant and flocculent separation, reverse osmosis, solvent extraction, and electrochemical advancements are used to decontaminate

\footnotetext{
${ }^{1}$ Department of Chemical Engineering,

Sathyabama Institute of Science and Technology, Chennai, India

${ }^{2}$ Department of Chemical Engineering,

SSN College of Engineering, Chennai-603110, India

$\triangle$ sathish.chemical@sathyabama.ac.in

(c) Deivasigamani P., Ponnusamy S.K., Sundararaman S., Suresh A, 2021
}

the polluted water [6]. However, these strategies are excessively expensive and inadequate for expulsion of heavy metals from defiled water [7]. Among all separation methods, adsorption phenomenon has a great deal of focal points like simple activity, exceptionally adaptable and ensuring productive expulsion of metals [8]. Nanosorbents have a tremendous potential towards wastewater remediation [9]. Especially the nanoscale zerovalent iron (nZVI) has been frequently applied in environmental remediation due to the small size, high specific surface area, and large surface activity. In addition, it also has major advantages like ecofriendly nature, non-toxicity, reusability and low prices $[10,11]$. However, nZVI has tendency to form aggregation due to the magnetic nature and rapid oxidation to metallic form of iron. Due to this, the reaction rate decreases, and surface sites are blocked [12]. Therefore, immobilizing or supporting nZVI by an inert material will be solution to the above-mentioned problem. Cashew nut shell (CNS) has been predominantly used for the preparation of activated carbon since it has high carbon content and low organic content [13]. In our previous study, cashew nut shell as support was found to be more effective in terms of stability and reduction of the aggregation for the treatment of heavy metals $[14,15]$.

The present study aims at expelling $\mathrm{Cd}$ (II) ions by promising cashew nut shell supported nano zerovalent iron (CNS-nZVI) nanoparticles through simple liquid phase reduction method. The effect of the newly synthesized (CNS-nZVI) material was aimed to study the process controlling parameters such as initial metal concentration, $\mathrm{pH}$, adsorbent dosage, and contact time. In addition, adsorption kinetics, isotherms of $\mathrm{Cd}$ (II) ions on CNS-nZVI were reported. The prepared adsorbent was characterized by different technique such as Fourier transform infrared spectroscopy (FTIR), transmission electron microscopy (TEM), scanning electron microscopy (SEM), X-ray diffraction (XRD) and thermogravimetric analysis (TGA). 


\section{Experimental}

\subsection{Chemicals and Materials}

Cadmium(II) sulfate octahydrate salt $\left(3 \mathrm{CdSO}_{4} \cdot 8 \mathrm{H}_{2} \mathrm{O}\right)$ was purchased from E.Merck chemicals, Mumbai, India. The solution $\mathrm{pH}$ was adjusted to the required value with $0.1 \mathrm{M} \mathrm{NaOH}$ or $0.1 \mathrm{M} \mathrm{HCl}$ using $\mathrm{pH}$ meter (HI 98107; Hanna Equipment, Mumbai, India). The concentration of $\mathrm{Cd}(\mathrm{II})$ ions in the solution was determined by Atomic Absorption Spectrometer (SL176 Model, Elico Limited, Chennai, India). The mixing process was performed by using temperature controlled shaking incubator (Royal Testing Equipments, Chennai, India).

\subsection{Preparation of the CNS-nZVI Composite}

The synthesis of cashew nut shell - nano zerovalent iron (CNS-nZVI) adsorbent was prepared by aqueous liquid-phase reduction process [16]. CNS was washed with deionized water to remove the dust particles and then washed shells were allowed to dry at the room temperature to remove moisture. By using a ball mill the dried agro waste material was made into fine powder. About $1.0 \mathrm{~g}$ of CNS material was washed with water and then soaked in saturated $\mathrm{FeSO}_{4} \cdot 7 \mathrm{H}_{2} \mathrm{O}$ solution along with concentrated $\mathrm{H}_{2} \mathrm{SO}_{4}$ for $30 \mathrm{~min}$. After that, the dissolved CNS with the saturated $\mathrm{FeSO}_{4} \cdot 7 \mathrm{H}_{2} \mathrm{O}$ solution was taken for sonication using an ultrasonic bath (SONICS Vibra
Cell, 750 Watts) for another $30 \mathrm{~min}$. Sonication results in the breaking of the CNS particle into the small pieces. After sonication completed $0.1 \mathrm{M} \mathrm{NaBH} 4$ was slowly added. The CNS along with the particles was exposed to double distilled water followed by a methanol wash to control the rust formation. Finally, the prepared adsorbent was kept in dryer and stored in an oxygen free nitrogen environment [17]. The prepared adsorbent was termed as surface modified nano zerovalent iron (Fig. 1).

\subsection{Characterization of CNS-nZVI}

The characterization study of CNS-nZVI was done by different techniques using Fourier transform infrared spectrometer (FTIR, Perkin Elmer FTIR C100566), scanning electron microscope (SEM-EDAX, Quanta 200 FEG), transmission electron microscope (TEM, Zeiss EM 900 with accelerating voltage of $80 \mathrm{kV})$, X-ray diffractometer (XRD, X'Pert Powder XRD System), and thermogravimetric analysis (TA Instruments Q5000IR analyzer, USA).

\subsection{Preparation of Stock and Standard Solutions}

A stock solution of cadmium ions $(100 \mathrm{mg} / \mathrm{l})$ was prepared by dissolving the measured amount of cadmium(II) sulfate octahydrate salt $\left(3 \mathrm{CdSO}_{4} \cdot 8 \mathrm{H}_{2} \mathrm{O}\right)$ in ultrapure water. Working and standard solutions were prepared from serial dilutions of the stock solutions. All chemicals used were of analytical grade (AR).

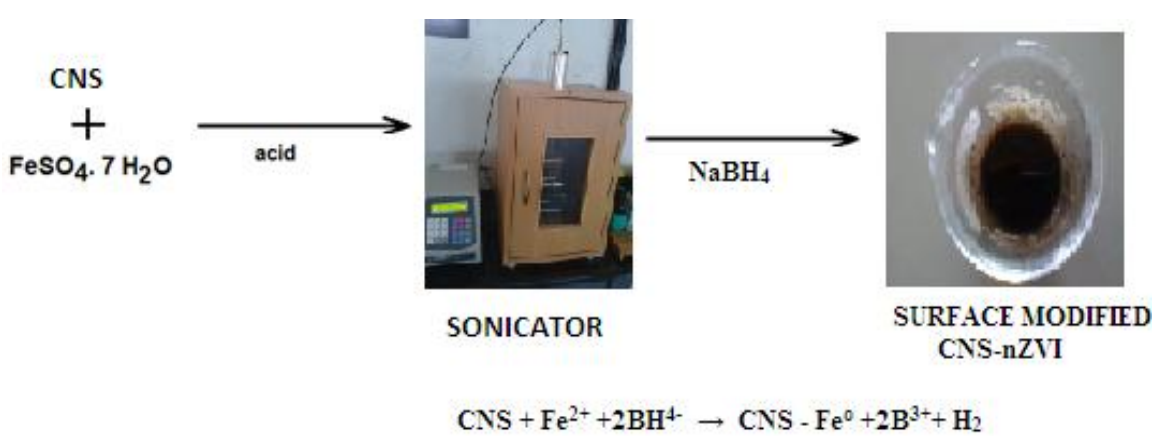

Fig. 1. Schematic representation of CNS-nZVI preparation

\subsection{Batch Adsorption Experiments}

Adsorption experiments were carried out batch wise to find the optimized process parameters, such as $\mathrm{pH}$, adsorbent dose, contact time, metal ions concentration for the maximum removal of $\mathrm{Cd}(\mathrm{II})$ ions from aqueous solution using CNS-nZVI. In order to perform batch adsorption studies, $100 \mathrm{ml}$ of cadmium ions solution with different initial Cd(II) concentrations $(20-100 \mathrm{mg} / \mathrm{l}), \mathrm{pH}$ (2.0-8.0), and adsorbent dosage $(0.5-3.0 \mathrm{~g} / \mathrm{l})$ were placed in $100 \mathrm{ml}$ Erlenmeyer flasks and then agitated in an incubation shaker. At definite time intervals (0-60 min) samples were taken for analysis to measure concentration of metals. Isotherm, kinetics and mechanism studies were performed. After the experiments, the used adsorbents were isolated by centrifugation and the clear liquid was measured by using AAS. The data obtained from the AAS analysis was used to calculate the $\mathrm{Cd}(\mathrm{II})$ ions removal percentage by the following equation: 


$$
\% \text { removal }=\left(\frac{C_{0}-C_{e}}{C_{0}}\right) \cdot 100
$$

where $C_{0}$ and $C_{e}$ are the initial and equilibrium concentrations of $\mathrm{Cd}(\mathrm{II})$ ions solution, respectively, $\mathrm{mg} / \mathrm{l}$.

\subsection{Adsorption Isotherm Studies}

Adsorption isotherm experiments were carried out by the addition of $0.2 \mathrm{~g}$ of adsorbent material (CNS-nZVI) to $100 \mathrm{ml}$ of the solution with the $\mathrm{Cd}(\mathrm{II})$ ion concentrations ranged from 20 to $100 \mathrm{mg} / \mathrm{l}$. After that the adsorption mixtures were kept in incubation shaker to reach its equilibrium time. Once the equilibrium time was reached, the flasks were taken from the incubation shaker and finally, the CNS-nZVI used was separated from the mixtures by centrifugation operation and the concentration of $\mathrm{Cd}(\mathrm{II})$ ion in the supernatant was analyzed by using atomic absorption spectroscopy (AAS, SL176 Model, Elico Limited, Chennai, India). Two adsorption isotherm models such as Langmuir and Freundlich models were used to explain the adsorption of $\mathrm{Cd}(\mathrm{II})$ ions. Finally, the correlation coefficient $\left(R^{2}\right)$ was compared for both models. Langmuir isotherm model and the equilibrium parameter are given by Eqs. (2) and (3):

$$
\begin{gathered}
q_{e}=\frac{q_{m} K_{L} C_{e}}{1+K_{L} C_{e}} \\
R_{L}=\frac{1}{1+K_{L} C_{0}}
\end{gathered}
$$

where $q_{e}$ is the equilibrium adsorption amount of metal ions adsorbed onto CNS-nZVI, $\mathrm{mg} / \mathrm{g} ; q_{m}$ is the maximum monolayer amount of metal ions adsorbed onto CNS$\mathrm{nZVI}, \mathrm{mg} / \mathrm{g} ; K_{L}$ is the Langmuir constant related to the affinity of the metal ions to the adsorbent, $1 / \mathrm{mg}$.

Freundlich isotherm model is given by Eq. (4):

$$
q_{e}=K_{F} C_{e}^{1 / n}
$$

where $q_{e}$ is the equilibrium adsorption amount of metal ions adsorbed onto CNS-nZVI, $\mathrm{mg} / \mathrm{g}$; $K_{F}$ is the constant related to the adsorption capacity of the adsorbent, $\left.(\mathrm{mg} / \mathrm{g})(1 / \mathrm{mg})^{(1 / \mathrm{n})}\right) ; n$ is the constant related to the intensity of the adsorption, $\mathrm{g} / \mathrm{l} ; C_{e}$ is the equilibrium concentration of metal ions solution, $\mathrm{mg} / \mathrm{l}$.

\subsection{Adsorption Kinetic Studies}

$0.2 \mathrm{~g}$ of CNS-nZVI was added to $100 \mathrm{ml}$ of the solution with the $\mathrm{Cd}(\mathrm{II})$ ion concentrations ranged from 20 to $100 \mathrm{mg} / 1$. The conical flasks were kept for agitation using an incubation shaker and the samples were taken at definite time intervals (10-60 min). After centrifugation process, the $\mathrm{Cd}(\mathrm{II})$ ions concentration was found in the supernatant that was measured using AAS. The quantity of Cd(II) ions adsorbed by CNS-nZVI at time $t,(\mathrm{mg} / \mathrm{g})$, was calculated by Eq. (5):

$$
q_{t}=\frac{\left(C_{0}-C_{t}\right) V}{m}
$$

where $C_{0}$ and $C_{t}$ are the concentrations of initial $\mathrm{Cd}(\mathrm{II})$ ions and ions in the solution at time $t$, respectively, $\mathrm{mg} / \mathrm{l}$; $V$ is the volume of metal ions solution, $1 ; m$ is the mass of the CNS-nZVI, g. The adsorption kinetic data were tested with the adsorption kinetic models such as pseudo-first order and pseudo-second order kinetic models to explain the adsorption process. The kinetic models were used to test the adsorption data such as pseudo-first order and pseudo-second order kinetic models to explain the adsorption process.

Pseudo-first order kinetic model:

$$
\log \left(q_{e}-q_{t}\right)=\log q_{e}-\frac{k_{1}}{2.303} t
$$

Pseudo-second order kinetic model:

$$
\frac{t}{q_{t}}=\frac{1}{k_{2} q_{e}^{2}}+\frac{1}{q_{e}} t
$$

where $q_{e}$ is the equilibrium adsorption capacity, $\mathrm{mg} / \mathrm{g} ; q_{t}$ is the adsorption capacity at any time $t, \mathrm{mg} / \mathrm{g} ; k_{1}$ is the pseudo-first order kinetic rate constant, $\min ^{-1} ; t$ is the time, $\min ; k_{2}$ is the pseudo-second order kinetic rate constant, $\mathrm{g} / \mathrm{mg} \cdot \mathrm{min} ; k_{2} \cdot q_{e}{ }^{2}=h$, is the initial adsorption rate, $\mathrm{mg} / \mathrm{g} \cdot \min$.

\section{Results and Discussion}

\subsection{Particles Characterization}

The surface morphology of the prepared composite CNS-nZVI was studied using SEM analysis (Fig. 2a). SEM image clearly shows that CNS-nZVI composite exhibits rough, irregular and porous surface. The nano adsorbents are spherical in shape with the diameter of 50 $100 \mathrm{~nm}$. The chemical composition of the prepared adsorbent was found by using EDX analysis (Fig. 2b). The major elements present in the CNS-nZVI are: C $(30.5 \%)$, O (82.3\%), S (26.2\%), and Fe (40.1\%). The percentage of carbon and iron present in the adsorbent proved the presence of CNS and nZVI on the surface modified nano adsorbent [18].

TEM image of CNS-nZVI is shown in Fig. 3. It shows two layers: the core layer consists of dark granules $\mathrm{Fe}^{\circ}$ and the outer layer is carbon from cashew nut shell. The results of XRD analysis are given in Fig. 4. XRD shows the crystalline nature of the prepared CNS-nZVI. The pattern shows a weak and broad peak at about $2 \theta=44.5^{\circ}$, which were indexed to the (110) planes and are consistent with the XRD standard data (JCPDS no.06-0696) [19]. The presence of iron oxide with weak intensities in the XRD pattern of CNS-nZVI particles $\left(2 \theta=54^{\circ}, 63.5^{\circ}\right)$ was the result of surface oxidation of nZVI. 


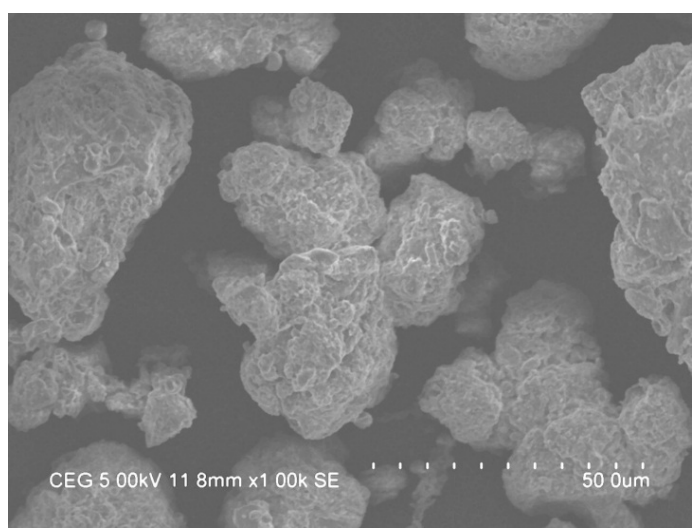

a)

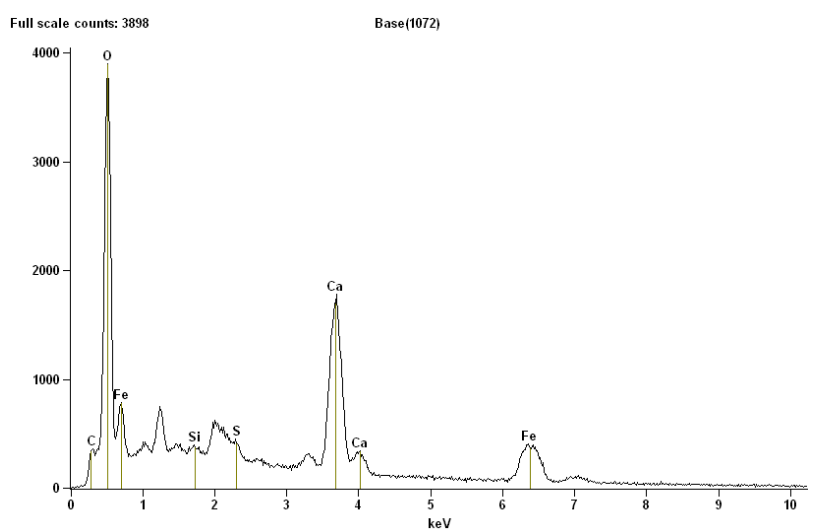

b)

Fig. 2. SEM (a) and EDX (b) images of CNS-nZVI

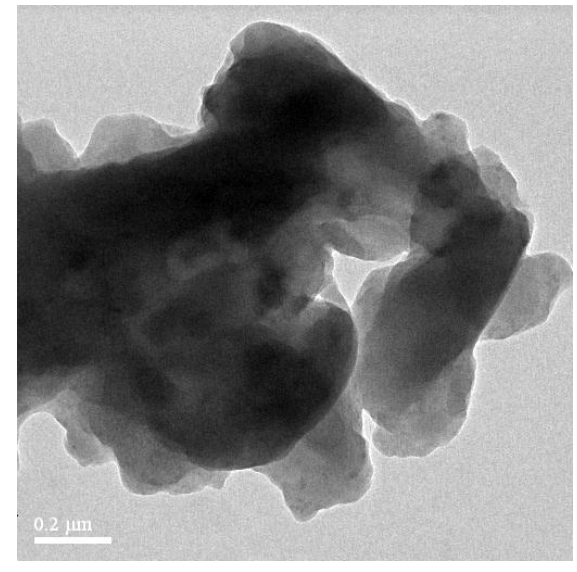

Fig. 3. TEM image of CNS-nZVI

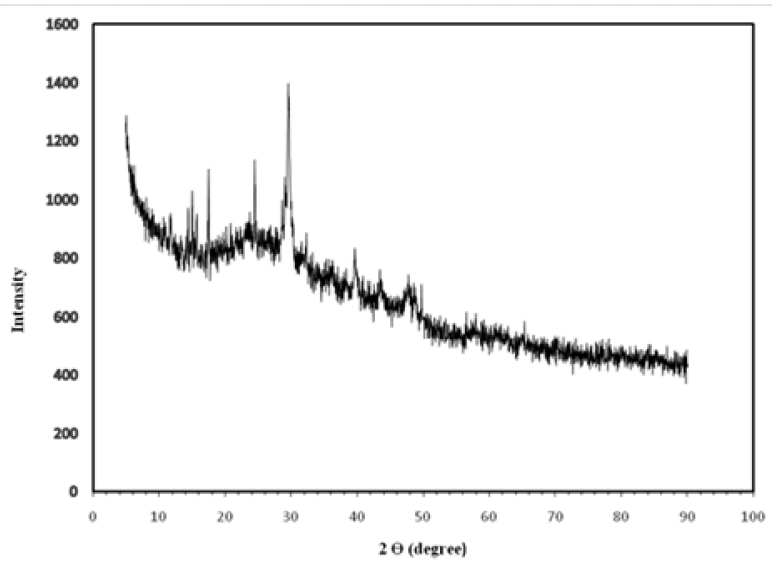

Fig. 4. XRD image of CNS-nZVI

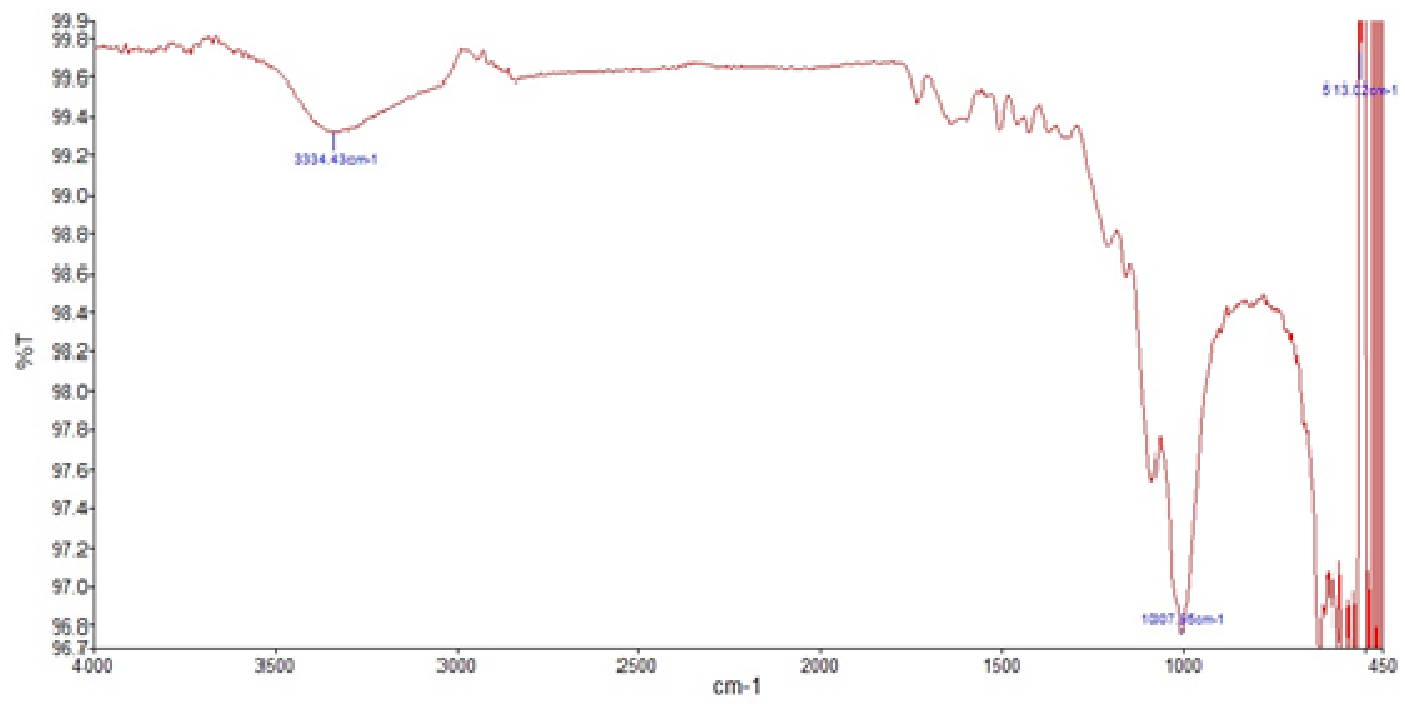

Fig. 5. FTIR spectra of CNS-nZVI 


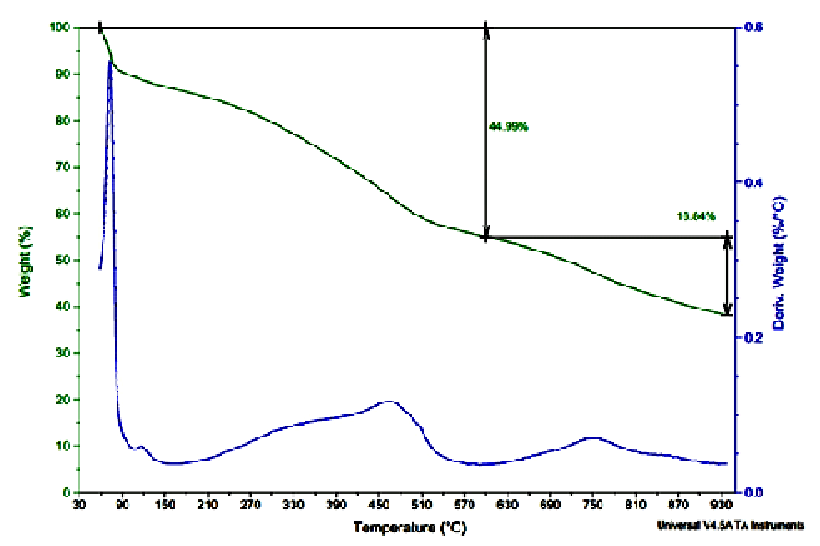

Fig. 6. TGA curves of the CNS-nZVI samples synthesized in this study

FTIR spectrum of CNS-nZVI (Fig. 5) shows that $\mathrm{Fe}^{\circ}$ nanoparticles are supported with cashew nut shell. The distinct bands in the spectrum are as follows: a broad and strong peak at $3350 \mathrm{~cm}^{-1}(\mathrm{O}-\mathrm{H}$ stretch); a weak band at $2910 \mathrm{~cm}^{-1}$ (C-H stretch); middle region shows strong bands at 1600 and $1450 \mathrm{~cm}^{-1}$ corresponding to asymmetric and symmetric $\mathrm{C}-\mathrm{O}-\mathrm{O}$ stretch), and $1003 \mathrm{~cm}^{-1}$ (C-O stretch). These findings help to understand the interactions between the components and the carboxyl groups in the active sites of the nano adsorbent. Fig. 6 shows the TGA plot of the CNS-nZVI under $\mathrm{N}_{2}$ atmosphere. Upon increasing the temperature, the first weight loss of $44.9 \%$ was mainly due to the water loss in the sample. The second weight loss of $16.84 \%$ was due to the dehydroxylation of $\mathrm{OH}$ groups. This indicates that the thermal stability of CNS-nZVI is mainly driven by the cashew nut shell.

\subsection{Factors Affecting the Removal of $\mathrm{Cd}(\mathrm{II})$}

\subsubsection{Effect of pH}

The $\mathrm{pH}$ of the solution is one of the most important factors for the adsorption of Cd(II) ions onto CNS-nZVI. The effect of solution $\mathrm{pH}$ on the adsorption of Cd(II) ions is shown in Fig. 7. The adsorption experiments were carried out in the initial $\mathrm{pH}$ range of 2.0-8.0. At low $\mathrm{pH}$, the removal and equilibrium adsorption capacity $\left(q_{e}\right)$ values are as low as the number of available hydronium ions is high in the solution and the $\mathrm{Cd}$ (II) ions compete with them for the adsorption sites. Point of zero charge is the $\mathrm{pH}$ at which the adsorbent surface is neutral. At $\mathrm{pH}>\mathrm{pH}_{\mathrm{pzc}}$, the negative charges on the adsorbent surfaces was increased hence the cation adsorption capacity gets increased. In the present adsorption system, $\mathrm{pH}_{\mathrm{pzc}}$ of the adsorbent was found to be greater than 6.0 and it was indicated that at $\mathrm{pH}>6 \mathrm{Cd}$ (II) ions precipitated as metal hydroxide. These results are in good agreement with those of previous studies for several sorbents. Under alkaline conditions, however, adsorption efficiency decreases due to the formation of metal hydroxides and concentration of $\mathrm{Cd}(\mathrm{II})$, as reported in the literature [20]. So, the $\mathrm{pH} 6.0$ was considered to be an optimum $\mathrm{pH}$ for the present adsorption system.

\subsubsection{Effect of adsorbent dosage}

The effect of adsorbent dosage on the adsorption of $\mathrm{Cd}$ (II) ions onto CNS-nZVI is shown in Fig. 8. The removal of $\mathrm{Cd}(\mathrm{II})$ ions was increased with the increase in CNS-nZVI dosage but the equilibrium adsorption capacity $\left(q_{e}\right)$ was decreased. This may be due to the increase in the number of available active sites with the increase in the CNS-nZVI dosage. The results show that $2.0 \mathrm{~g} / 1$ has enough exchangeable sites for the removal of Cd(II) ions. Further increase in the adsorbent dosage does not lead to the significant changes in the $\mathrm{Cd}(\mathrm{II})$ ions removal. This indicated that after a certain dosage of CNS-nZVI, the maximum removal of $\mathrm{Cd}(\mathrm{II})$ ions was observed and hence the amount of $\mathrm{Cd}(\mathrm{II})$ ions adsorbed onto the CNS-nZVI and the amount of free $\mathrm{Cd}(\mathrm{II})$ ions remains constant even with further addition of CNS-nZVI, as observed by other researchers [21, 22]. The optimum dosage of CNS-nZVI was found to be $2 \mathrm{~g} / \mathrm{l}$ for the present adsorption system.

\subsubsection{Effect of $\mathrm{Cd}(\mathrm{II})$ ions concentration}

As shown in Fig. 9, the equilibrium adsorption capacity $q_{e}$ was increased with the increase in the initial $\mathrm{Cd}(\mathrm{II})$ ions concentration; however, the percentage removal of $\mathrm{Cd}$ (II) ions was decreased. The $q_{e}$ values increased from 12.473 to $65.686 \mathrm{mg} / \mathrm{g}$, while the percentage removal decreased from 99.785 to $87.582 \%$ with the increase in initial $\mathrm{Cd}(\mathrm{II})$ ions concentration from 20 to $100 \mathrm{mg} / \mathrm{l}$. At higher initial cadmium ion concentration, the number of moles of cadmium ions available to the surface area was high, so the functional adsorption depends on the initial cadmium ions concentration. This proves that the effect of initial cadmium ion concentration depends on the adsorbent surface saturation. This initial cadmium ions concentration provides the driving force to overcome all mass transfer resistance of cadmium ions between the aqueous solution and solid adsorbent [23, 24]. At lower cadmium ions concentration, the ratio of surface active sites to the cadmium ions in the aqueous solution might be high and hence all the cadmium ions may interact with the solid adsorbent and the cadmium ions were removed from the aqueous solution [25]. 


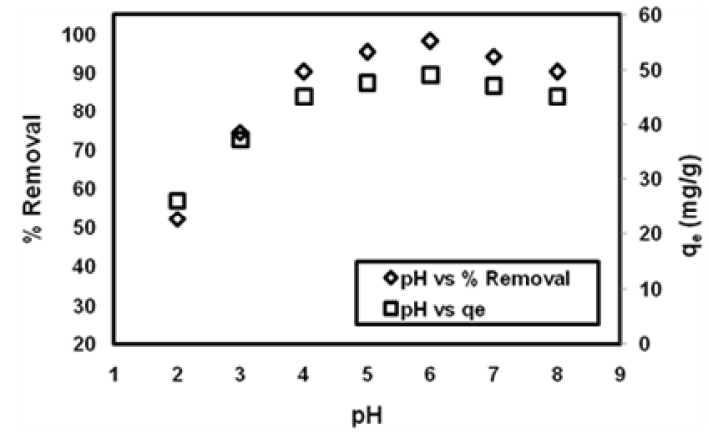

Fig. 7. Effect of solution $\mathrm{pH}$ for the adsorption of cadmium ions onto CNS-nZVI (cadmium ions concentration is $20 \mathrm{mg} / \mathrm{l}$, adsorbent dose is $2 \mathrm{~g} / \mathrm{l}$, sample volume is $100 \mathrm{ml}$, equilibrium time is $30 \mathrm{~min}$ )

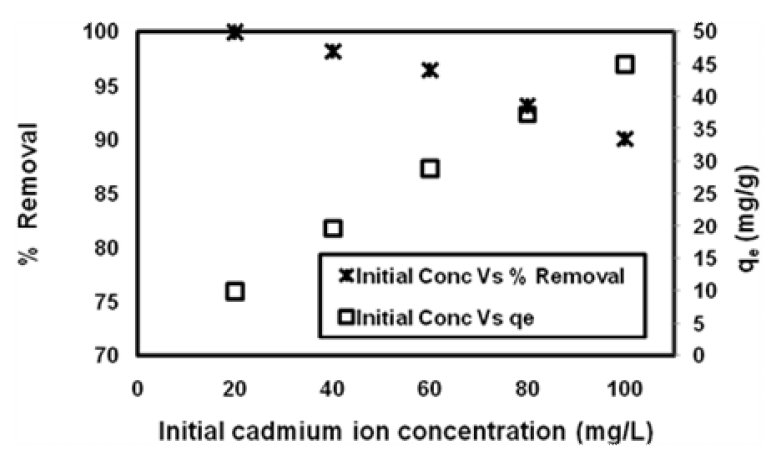

Fig. 9. Effect of initial cadmium ions concentration for the adsorption of cadmium ions onto CNS-nZVI (solution $\mathrm{pH}$ is 6.0 , adsorbent dose is $2 \mathrm{~g} / \mathrm{l}$, sample volume is $100 \mathrm{ml}$, equilibrium time is $30 \mathrm{~min}$ )

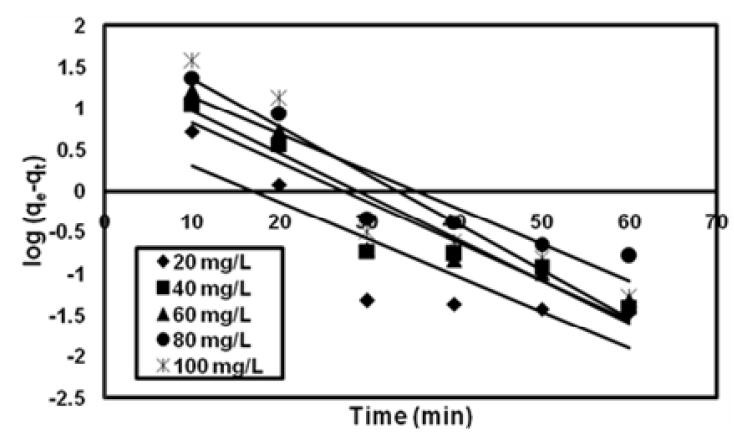

Fig. 11. Pseudo-first order adsorption kinetics plots for the removal of cadmium ions by CNS-nZVI (cadmium ion concentration is $20-100 \mathrm{mg} / \mathrm{l}$, sample volume is $100 \mathrm{ml}$, solution $\mathrm{pH}$ is 6.0 , adsorbent dose is $2 \mathrm{~g} / \mathrm{l}$ )

\subsubsection{Effect of contact time and adsorption kinetics}

The effect of contact time on the adsorption of $\mathrm{Cd}(\mathrm{II})$ ions onto CNS-nZVI was studied using aqueous solutions with the $\mathrm{Cd}(\mathrm{II})$ ion concentration of $20 \mathrm{mg} / \mathrm{l}$,

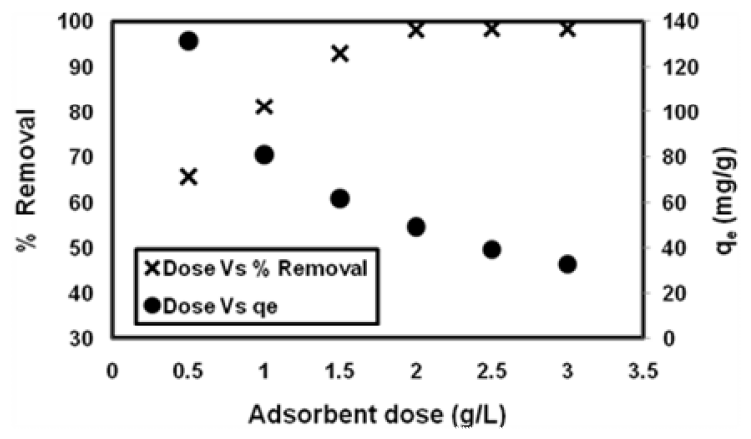

Fig. 8. Effect of adsorbent dose for the adsorption of cadmium ions onto CNS-nZVI (cadmium ions concentration is $20 \mathrm{mg} / \mathrm{l}$, solution $\mathrm{pH}$ is 6.0 , sample volume is $100 \mathrm{ml}$, equilibrium time is $30 \mathrm{~min}$ )

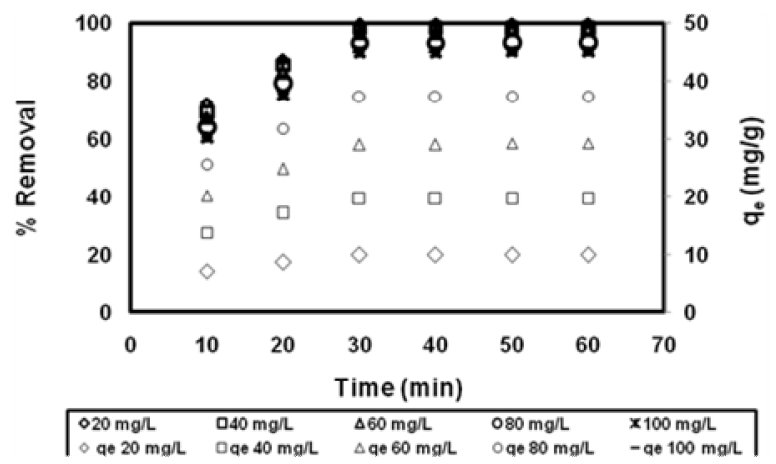

Fig. 10. Effect of contact time for the adsorption of cadmium ions onto CNS-nZVI (cadmium ions concentration is $20 \mathrm{mg} / \mathrm{l}$, solution $\mathrm{pH}$ is 6.0 , sample volume is $100 \mathrm{ml}$ )

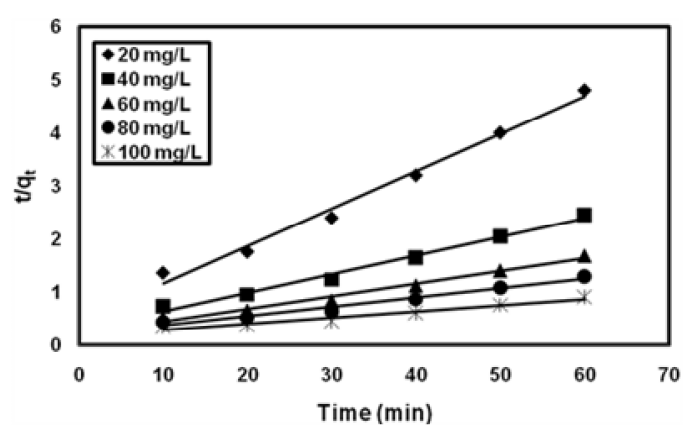

Fig. 12. Pseudo-second order adsorption kinetics plots for the removal of cadmium ions by CNS-nZVI (cadmium ion concentration is $20-100 \mathrm{mg} / \mathrm{l}$, sample volume is $100 \mathrm{ml}$, solution $\mathrm{pH}$ is 6.0 , adsorbent dose is $2 \mathrm{~g} / \mathrm{l}$ )

$\mathrm{pH}=6.0$, adsorbent dose $=2 \mathrm{~g} / \mathrm{l}$ at the temperature of $303 \mathrm{~K}$ for different contact time ranging from 10 to $60 \mathrm{~min}$; the results are shown in Fig. 10. It is observed that from 10 to $30 \mathrm{~min}$ the removal of $\mathrm{Cd}$ (II) ions was quite high. Initially, the percentage removal and adsorption capacity $q_{e}$ values were high, which may be due to a 
larger surface area of the adsorbent being available for the removal of cadmium ions [26]. Further increase in contact time did not show any increase in percentage removal due to the saturation of adsorption sites and weakening of driving force.

The adsorption kinetics data were used to predict the adsorption rate and adsorption mechanism between the cadmium ions and CNS-nZVI. From the tabulation report, the pseudo-second order kinetic model and the experimental data converged very well with the excellent $R^{2}(>0.98)$. The pseudo-second order constants $k_{2}, h$ and $q_{e, c a l}$ were estimated from the slope and intercept of the $t / q_{t} v s t$ plot (Figs. 11, 12) and given in Table 1. The results show that the $q_{e, c a l}$ values from the pseudo-second order kinetic model are in a good agreement with the $q_{e \text { exp }}$ values, which confirms the applicability of this model for the present adsorption system. Finally, the present adsorption system follows the pseudo-second order kinetic model [27, 28].

\subsection{Adsorption Isotherm}

Adsorption isotherm plays an important role in describing the relationship between the adsorbate on the adsorbent and adsorbate in the liquid solution at equilibrium condition [29]. In the present study, the models (Figs. 13 and 14) were used to calculate the adsorption equilibrium between the cadmium ions and CNS-nZVI. The calculated values of adsorption isotherm parameters $\left(q_{m}, K_{L}, K_{F}, n\right)$ along with the coefficient of determination $\left(R^{2}\right)$ and error values (SSE and RMSE) were summarized in Table 2. Based on the $R^{2}$ and error values from the Table, the adsorption equilibrium data can be well described by the Freundlich adsorption isotherm model. Freundlich isotherm model yields a best fit to the experimental data than the Langmuir models, which indicates that adsorption of $\mathrm{Cd}(\mathrm{II})$ ions onto CNS-nZVI is multilayer adsorption and heterogeneous in nature. The maximum monolayer adsorption capacity was found to be $35.58 \mathrm{mg} / \mathrm{g}$.

Table 1

Adsorption kinetics parameters for the removal of Cd(II) ions by CNS-nZVI

\begin{tabular}{|c|c|c|c|c|c|c|}
\hline \multirow{2}{*}{ Adsorption models } & \multirow{2}{*}{ Parameters } & \multicolumn{5}{|c|}{ Concentration of cadmium ions solution, $\mathrm{mg} / \mathrm{l}$} \\
\hline & & 20 & 40 & 60 & 80 & 100 \\
\hline \multirow{3}{*}{$\begin{array}{c}\text { Pseudo-first order kinetic } \\
\text { equation }\end{array}$} & $k_{1}, \min ^{-1}$ & 0.1013 & 0.1082 & 0.1175 & 0.1244 & 0.1313 \\
\hline & $q_{e, c a l}, \mathrm{mg} / \mathrm{g}$ & 5.636 & 19.815 & 29.785 & 38.019 & 84.722 \\
\hline & $R^{2}$ & 0.760 & 0.883 & 0.862 & 0.857 & 0.876 \\
\hline \multirow{5}{*}{$\begin{array}{l}\text { Pseudo-second order kinetic } \\
\text { equation }\end{array}$} & $k_{2}, \mathrm{~g} / \mathrm{mg} \cdot \min$ & 0.0107 & 0.0043 & 0.0032 & 0.0019 & 0.0012 \\
\hline & $q_{e, c a l}, \mathrm{mg} / \mathrm{g}$ & 14.286 & 28.571 & 38.46 & 52.632 & 71.429 \\
\hline & $h, \mathrm{mg} / \mathrm{g} \cdot \mathrm{min}$ & 2.188 & 3.509 & 4.739 & 5.128 & 5.988 \\
\hline & $q_{e, \exp }, \mathrm{mg} / \mathrm{g}$ & 12.521 & 24.503 & 35.495 & 46.152 & 65.996 \\
\hline & $R^{2}$ & 0.988 & 0.987 & 0.983 & 0.976 & 0.956 \\
\hline
\end{tabular}

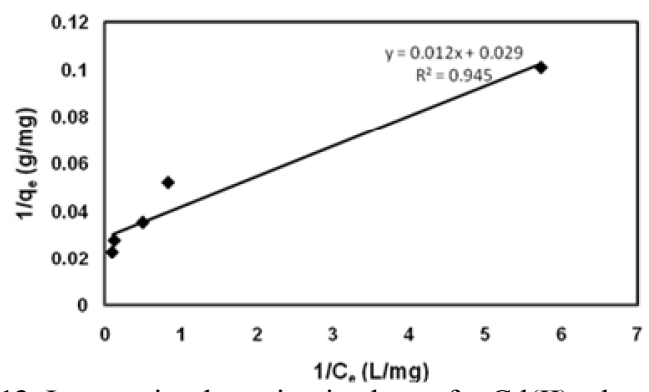

Fig. 13. Langmuir adsorption isotherm for $\mathrm{Cd}(\mathrm{II})$ adsorption onto CNS-nZVI

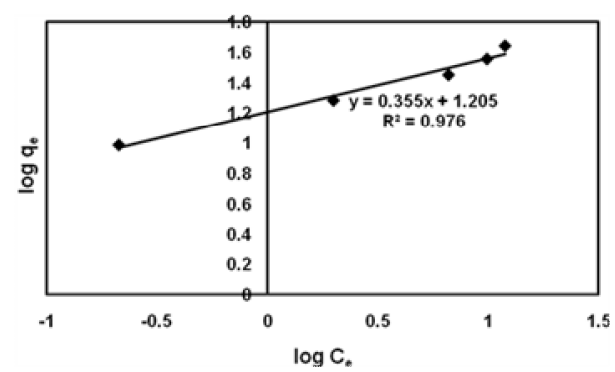

Fig. 13. Freundlich adsorption isotherm for $\mathrm{Cd}(\mathrm{II})$ adsorption onto CNS-nZVI

Table 2

Adsorption isotherm parameters for the removal of $\mathrm{Cd}(\mathrm{II})$ ions by the CNS-nZVI

\begin{tabular}{|c|c|c|c|}
\hline Adsorption isotherm model & Parameters & Values & $R^{2}$ \\
\hline \multirow{3}{*}{ Langmuir } & $q_{m}, \mathrm{mg} / \mathrm{g}$ & 35.58 & \\
& $K_{L}, 1 / \mathrm{mg}$ & 0.795 & 0.9452 \\
& $\mathrm{SSE}$ & 109.2 & \\
\hline \multirow{3}{*}{ Freundlich } & $\mathrm{RMSE}$ & 5.97 & \\
& $K_{F},(\mathrm{mg} / \mathrm{g})(1 / \mathrm{mg})^{(1 / \mathrm{m})}$ & 1.97 & 0.9769 \\
& $n, \mathrm{~g} / \mathrm{l}$ & 23.56 & \\
\hline
\end{tabular}




\section{Conclusions}

In summary, the environmental friendly nanocomposite CNS-nZVI showed good removal efficiency for $\mathrm{Cd}(\mathrm{II})$ removal by surface modified nZVI nanoparticles via borohydride reduction method. The prepared nanocomposite CNS-nZVI was characterized by TEM, SEM, XRD, FT-IR, and TGA analyses. The morphological characterization was analyzed by SEM, which showed that CNS-nZVI has large porous in structure. The presence of carbon and iron were proved by EDX. The study showed that CNS-nZVI could be used as an adsorbent for $\mathrm{Cd}(\mathrm{II})$, and the optimum conditions were found ( $\mathrm{pH} 6$, adsorbent mass $2 \mathrm{~g} / \mathrm{l}$, initial concentration $20 \mathrm{mg} / \mathrm{l}$, and contact time $60 \mathrm{~min}$ ). The adsorption process was greatly influenced by the operating parameters such as solution $\mathrm{pH}$, adsorbent dose, initial $\mathrm{Cd}$ (II) ions concentration, contact time. The adsorption of $\mathrm{Cd}(\mathrm{II})$ ions onto the CNSnZVI was well explained by the Freundlich adsorption isotherm model, whereas the kinetic study corresponds to a pseudo-second order kinetic equation. Finally, our results indicated that the CNS-nZVI materials can be prepared at low cost and they are environmentally friendly for the removal of $\mathrm{Cd}(\mathrm{II})$ ions. For future work, these nanocomposites should be evaluated for regeneration potential in fixed bed columns.

\section{References}

[1] Rout K., Mohapatra M., Anand S.: Dalton Transact., 2012, 41, 3302. https://doi.org/10.1039/c2dt11651k

[2] Salem N., Farhan A., Awwad A.: Am. J. Environ. Eng., 2012, 2,

123. https://doi.org/10.5923/j.ajee.20120205.02

[3] Keshvardoostchokami M., Babaei L., Zamani A. et al.: Global J. Environ. Sci. Manage., 2017, 3, 267.

https://doi.org/10.22034/GJESM.2017.03.03.004

[4] Smara A., Delimi R., Chainet E., Sandeaux J.: Sep. Purif.

Technol., 2007, 57, 103. https://doi.org/10.1016/j.seppur.2007.03.012

[5] Zamani A., Shokri R., Yaftian M., Parizanganeh A.: Int. J. Environ.

Sci. Technol., 2013, 10, 93. https://doi.org/10.1007/s13762-012-0107-x

[6] Garg U., Kaur MP, Garg VK et al.: J. Hazard. Mater., 2007, 140,

60. https://doi.org/10.1016/j.jhazmat.2006.06.056

[7] Fu F., Ma J., Xie L. et al.: J. Environ. Manage., 2013, 128, 822. https://doi.org/10.1016/j.jenvman.2013.06.044

[8] Li L., Hu J., Shi X. et al.: Environ. Sci. Pollut. Res., 2016, 23,

17880. https://doi.org/10.1007/s11356-016-6626-0

[9] Crane R., Scott T.: J. Hazard. Mater., 2012, 211-212, 112.

https://doi.org/10.1016/j.jhazmat.2011.11.073

[10] Prabu D., Parthiban R., Senthil Kumar P. et al.: IET

Nanobiotechnology, 2017, 11, 714. https://doi.org/10.1049/IETNBT.2016.0224

[11] Zhou Y., Wang D., Li Y.: Chem. Commun., 2014, 50, 6141. https://doi.org/10.1039/C4CC02081B

[12] Sun C., Chen T., Huang Q. et al.: Environ. Sci. Pollut. Res., 2019, 26, 8902. https://doi.org/10.1007/s11356-019-04321-z
[13] Zhang C., Shan B., Tang W., Zhu Y.: Biores. Technol., 2017, 238, 352. https://doi.org/10.1016/j.biortech.2017.04.051

[14] Yu D., Goh K., Wang H. et al.: Nat. Nanotechnol., 2014, 9, 555. https://doi.org/10.1038/nnano.2014.93

[15] Zhao D., Teng W., Fan J. et al.: J. Mater. Chem. A., 2017, 5, 4478. https://doi.org/10.1039/C6TA10007D

[16] Ponder S., Darab J., Mallouk T.: Environ. Sci. Technol., 2000, 34, 2564. https://doi.org/10.1021/es9911420

[17] Ngomsik A., Bee A., Siaugue J. et al.: J. Hazard. Mater., 2009, 166, 1043. https://doi.org/10.1016/j.jhazmat.2008.11.109.

[18] Bai L., Yuan L., Ji Y., Yan H.: Arab. J. Sci. Eng., 2018, 43, 3611. https://doi.org/10.1007/s13369-018-3124-3

[19] Kumar P., Saravanan A., Rajan P., Yashwanthraj M.: Text. Cloth. Sustain., 2017, 2, 1. https://doi.org/10.1186/s40689-016-0014-5 [20] Gupta A., Yunus M., Sankararamakrishnan N.: Chemosphere, 2012, 86, 150. https://doi.org/10.1016/j.chemosphere.2011.10.003.

[21] Teymouri P., Ahmadi M., Babaei A. et al.: Chem. Eng. Commun., 2013, 200, 1394.

https://doi.org/10.1080/00986445.2012.744748

[22] Anirudhan T., Sreekumari S.: J. Environ. Sci., 2011, 23, 1989. https://doi.org/10.1016/S1001-0742(10)60515-3

[23] Azari A., Kalantary R., Ghanizadeh G. et al.: RSC Adv., 2015, 106, 87377

[24] Tang Y., Liang S., Yu S. et al.: Colloids Surf. A, 2012, 406, 61. https://doi.org/10.1016/j.colsurfa.2012.04.050

[25] Huang J., Wu Z., Chen L., Sun Y.: J. Mol. Liq., 2015, 209, 753. https://doi.org/10.1016/j.molliq.2015.06.047

[26] Kakavandi B., Kalantary R., Jafari A. et al.: Clean - Soil, Air, Water, 2015, 43, 1157. https://doi.org/10.1002/clen.201400568

[27] Azari A., Kakavandi B., Kalantary R. et al.: J. Porous Mat., 2015, 22, 1083. https://doi.org/10.1007/s10934-015-9983-z

[28] Ren L., Xu J., Zhang Y. et al.: Int. J. Biol. Macromol., 2019, 135, 898. https://doi.org/10.1016/j.ijbiomac.2019.06.007

[29] Rao M., Ramana D., Seshaiah K. et al.: J. Hazard. Mater., 2009, 166, 1006. https://doi.org/10.1016/j.jhazmat.2008.12.002

Received: December 17, 2019 / Revised: February 11, 2020 / Accepted: July 03, 2020

\section{АДСОРБЦІЯ ЙОНІВ КАДМІЮ(II) МОДИФІКОВАНИМ КОМПОЗИТОМ З НАНОЧАСТИНКАМИ НУЛЬ-ВАЛЕНТНОГО ЗАЛІЗА (CNS-nZVI): ХАРАКТЕРИСТИКА, КІНЕТИКА АДСОРБЦІЇ ТА ІЗОТЕРМІЧНІ ДОСЛІДЖЕННЯ}

\begin{abstract}
Анотація. Досліджено ефективність поверхнево модифікованого композиту нанорозмірне нуль-валентне залізо/ шкарлупа горіха кеш'ю (CNS-nZVI) для вилучення йонів кадмію у водних розчинах. Встановлено, що CNS-nZVI у кількості 2 г/л $\epsilon$ ефективним для видалення $98 \%$ кадмію. Визначено, щзо адсорбиійна здатність становила 35,58 мг/2. Показано, що ізотерма Фрейндліха $(R 2=0,9769)$ та дані про кінетику адсорбиії псевдо-другого порядку добре узгоджуються. Цим підтверджено, щчо CNS-nZVI має високу ефективність видалення $C d(I I)$ з водних розчинів.
\end{abstract}

Ключові слова: нанокомпозит, икаралупа горіха кеш'ю, адсорбиія, nZVI, ізотерма, кінетика. 